\title{
CHILDREN AND YOUNG PEOPLE'S SOCIAL MEDIA PLATFORMS BENEFITS AND IMPLICATIONS
}

\author{
Lela Susanty ${ }^{1}$, Ardian Arifin², Darmadi ${ }^{3}$, Yuliana ${ }^{4}$, Ismawati ${ }^{5}$, Ahdi Topan Sofyan ${ }^{6}$. \\ ${ }^{1}$ STBA YAPARI ABA Bandung \\ ${ }^{2}$ IKIP PGRI Pontianak, \\ ${ }^{3}$ Universitas PGRI Madiun \\ ${ }^{4}$ Universitas Pasifik Morotai \\ ${ }^{5}$ Universitas Samawa NTB \\ ${ }^{6}$ Universitas Cordova NTB \\ *Korespodensi: ardian.arifin@yahoo.com
}

\begin{abstract}
This research aims to show the positive effects and the negative social media on the growth of young people. This discussion brings together the work of various fields of study the association between social media and social capital, personal safety of young people, psychological well-being, and learning performance. This research takes information from some of the posts that cover the same topic. Those selected are regular users of social media. The methodology used in this research is to use literature research with a theoretical framework developed for synthesis. The research shows that children and young people terbawa- bring positive social media to help improve their communication skills, get data, improve their technological expertise, as well as how they can use the latest technology efficiently. On the other hand, they are at risk of Facebook's mental stress, cyberbullying, as well as online intimate harassment. The conclusion of this research is a social media platform is a very important role in the lives of young people every day. They find benefits by improving communication skills with friends and relatives and they can further improve their socialization process. Not only that, it can be said that young people can use social media to obtain data on topics such as health, education, as well as for improving the technical expertise using the latest technology.
\end{abstract}

\section{ABSTRAK}

Penelitian ini bertujuan untuk menunjukkan dampak positif dan negatif media sosial terhadap perkembangan remaja. Ulasan ini menyatukan pekerjaan dari berbagai bidang yang meneliti hubungan antara media sosial dan modal sosial, privasi, keamanan remaja, kesejahteraan psikologis, dan prestasi pendidikan. Penelitian ini mengambil data dari beberapa artikel yang mengupas tentang topik yang sama. Mereka yang terpilih adalah pengguna biasa media sosial. Metode yang digunakan dalam penelitian ini adalah menggunakan studi literatur dengan kerangka teori yang dikembangkan untuk sintesis. Studi ini menunjukkan bahwa anak-anak dan remaja terpengaruh secara positif karena media sosial membantu meningkatkan keterampilan komunikasi mereka, memperoleh informasi, mengembangkan keterampilan teknologi mereka, dan bagaimana mereka dapat menggunakan teknologi terkini secara efektif. Di sisi lain, mereka berisiko mengalami depresi Facebook, penindasan maya, dan pelecehan seksual online. Bagian kesimpulan dari penelitian ini adalah media sosial merupakan platform yang sangat penting dalam kehidupan remaja sehari-hari. Mereka mendapat manfaat dengan meningkatkan keterampilan komunikasi dengan teman dan kerabat dan mereka dapat lebih mengembangkan proses sosialisasi mereka. Selain itu, dapat dikatakan bahwa remaja dapat menggunakan media sosial untuk mendapatkan informasi tentang topik seperti kesehatan, pendidikan, dan untuk meningkatkan keterampilan teknis dengan menggunakan teknologi terkini. 
Keyword: Social media, benefits, risk, teenagers, children

\section{INTRODUCTION}

Young people today use social networking a lot. They have made this a part of their daily activities. Every web park website that allows social interaction is misinterpreted as a social media website. These pages include social networking pages such as Facebook, Twitter, Instagram, Myspace; website games and virtual worlds such as Club Penguin, Second Life, and Sims; video websites such as YouTube; as well as websites. As a result, these sites offer young people today a portal for entertainment and communication. Borne on the survey results was established if the increase, $73 \%$ of young American was here wearing a social networking website (Lara \& Naval, 2012). Other research shows that $22 \%$ of young people get into social networking options those more than 10 times per day, and half of young dreamy, go into this social media more than once per day (James \& James, 2009)

Other research has been attempted by the Childrens Online Privacy Protection Act (Federal Trade Commission, 2002). Take research in 144 web site for sure whether they collect data from individual children online, and, if so, for recognizing the type of data they collect. The survey showed that 104 websites $(72 \%)$ collect individual data online. Almost 2 thirds $(63 \%)$ of 104 websites to collect the full name of the child, while $85 \%$ collect email addresses of children. 7 percent collect parental property.

full name, as well as $45 \%$ collecting the parent's email address. More than half (56\%) collect other people's email addresses, often in connection with electronic postcard activity. Only $9 \%$ of the web collects phone numbers, $14 \%$ collects full home addresses or other messaging addresses, and none collects fax numbers or Social Security numbers.

Types of PERsonal information Collected

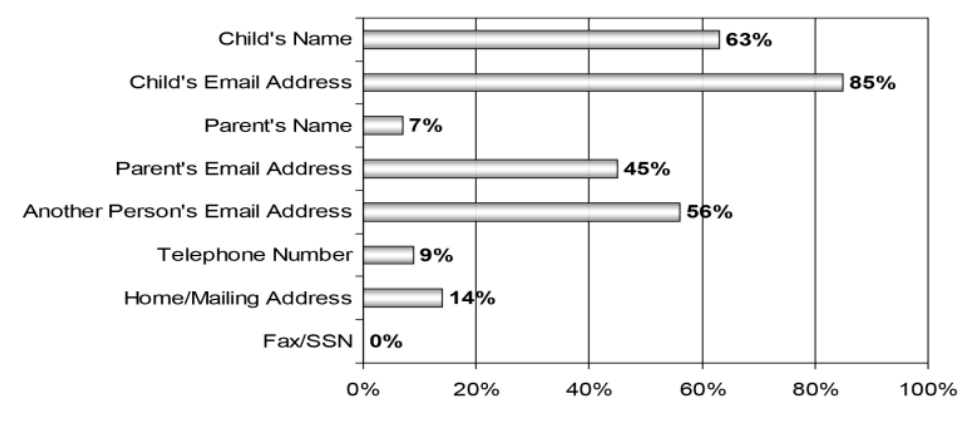

Figure 1: Type of Personal Information Collected

On the one hand, the internet has many opportunities for learning, entertainment, enrichment, and development of people. Therefore, parents have positive thoughts about their use, and urge children and young people do use it legally. On the other hand, parents are ambivalent towards the internet, because they are aware of the potential risks it poses by exposing users to negative content such as pornography, violence, commercialism, turbulent cybe, unsupervised social bonds, and individual and security issues. (Ceyhan, 2011)Many scholars recommend that students learn in new ways using social media as well as educators must embrace this new platform (Ito, 2013). Uniform facebook and social media programs allow students to gather outside the classroom with the aim of collaborating and exchanging inspiration about tasks (Surjandy, 2017) 
In this study, the risk and benefits of using social media in the children and young people studied empirically. This post is broken down into the following sections. Initially, some background data on social media was provided. Next reflection on the efficacy of social media, the efficacy of youngsters wearing media and social risks faced by children and young people who use social media. Further research models and hypotheses will be discussed in this post. This is accompanied by the methodology used as well as the research results. At the end of the post, we want to share a conclusion.

\section{Literature Review}

\section{What is Social Media?}

"Social media is a group of Internet -based applications built on the ideological foundation and technology of Website 2.0, and that allows the creation and exchange of user -created content." (Kaplan \& Haenlein, 2010)(Ghani et al., 2019)(Özçakir et al., 2015)(Ghani et al., 2019). The foundation of social media is social interaction, which gives participants the possibility to share opinions, thoughts, and knowledge in a global forum where time and place are insignificant(Tikly \& Barrett, 2011)(Podobnik et al., 2013). (Podobnik et al., 2013) Website 2.0 contains social networks and communities such as Pirate Bay and My Space, the web, and the web where participants create their own content, such as Facebook. Website 2.0 is a platform that is the basis of social media (Wright Joe, 2015)(Qi et al., 2018) (Qi et al., 2018)The term Web 2.0 refers to websites designed to: (a) rely on the participation of mass groups of users and centrally controlled content providers, (b) aggregate and remix content from various sources, and (c) more intense, network users and content together (O'reilly, 2007). (Zafarani et al., 2014,) (Zafarani et al., 2014) Bis a type of social media platform: blogs, microblogging sites (e.g. Twitter), media sharing sites (e.g. YouTube), social bookmarking sites (e.g. StumbleUpon),bulletinboards, and social networking sites (e.g. Facebook). (Kaplan \& Haenlein, 2010) also added virtual social worlds (e.g. Second Life), virtual game worlds (e.g., World of Warcraft), and collaborative projects (e.g., Wikipedia) to that list. In addition, these sites offer youth entertainment and communication opportunities. Therefore, engaging in various forms of social media is aroutineactivity that research has proven beneficial for children and adolescents by improving communication, social connections, and even technical skills(Ito et al., 2009)(Zachos et al., 2018). (Zachos et al., 2018)In recent years, the number of preteenagers and teens using the site has increased dramatically.

Media Users according to the results of research conducted by boc. web.id Facebook social media users ranked first with the number of users as many as 113.3 million users followed by Snapchat with a total of 66.9 million users, third-place Instagram with a total of 52.9 million users and lastly twitter with a total of 20.2 million users.

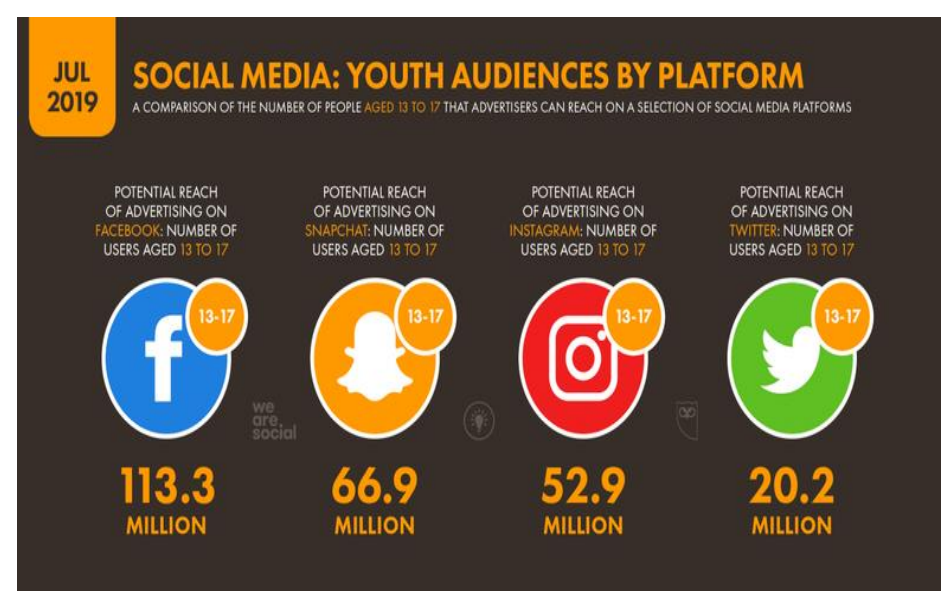


Figure 2. Social media users among teens

\section{Benefits of Teens in Using Social Media}

Social media through its interactive platform allows users to communicate with other members in building social relationships and sharing information and knowledge related to real-life needs and activities. Teenagers, spend a lot of their time interacting in their social lives. The use of social media by adolescents occurs at the same time as their identity, sexuality, and physical and moral development are evolving. Recent studies show some of the benefits these teens get because they have improved in communication. At the same time, they have also improved social life.

Social Media can also provide a supportive environment for teens to explore romance, friendship, social status, and give teens the opportunity to share and discuss their musical tastes, knowledge of television and movies, video games, and other aspects of youth culture (Ito et al., 2008).

\section{Socialization and Communication}

Social media sites allow teens to fulfill many online tasks relevant to their lives offline, making new friends, sharing photos, and sharing ideas. Social media participation can also offer deeper youth benefits that extend to their views of themselves, the community, and the world(Boyd, 2008). Thus, young people who spend more time on Facebook and can show "virtual empathy" to their online friends(Akram \& Kumar, 2017; Srivastava, 2012). Again, social media sites allow teens to complete many of the online tasks that are important to them offline: staying connected with friends and family, making new friends, sharing pictures, and exchanging ideas.

\section{Accessing Health Information}

Teenagers can find and access online information about their health problems easily and anonymously. Excellent healing resources are increasingly available to adolescents on a variety of topics of interest, such as sexually transmitted infections, stress reduction, and signs of depression(O'Keeffe \& Clarke-Pearson, 2011). However, the urge of parents to be more informed about their children's online accession will go a long way in getting more information and will lead to a more in-depth discussion of the issue.

According to Lenhart et al. (2010), teens also use online search to get answers to many of their health problems with $31 \%$ of online teens getting health, diet, or physical fitness information. $17 \%$ of teens who use the internet, report they use it to gather information about health topics that are difficult to discuss with others, such as drug use and sexual health.

\section{Enhanced Learning Opportunities}

Various studies conducted on the effects of social media emerged from the results seen when people used new media and technologies that evolved. Many scholars suggest that students learn in new ways using social media; and thus, educators should embrace this new platform. Middle and high school students use social media to connect with one another on homework and group projects. Some schools successfully use blogs as teaching tools that have the benefit of strengthening skills in English, written expression, and creativity (Borja, 2005). In addition, social media programs allow students to gather outside the classroom for the purpose of collaborating and exchanging ideas about assignments. Social networks can provide tools to teach in interesting ways involving young students. 


\section{Risks of using Social Media.}

In addition to its benefits, social media also carries threats to teenagers. They are at risk if they access the internet under their age without their parents' permission. The minimum age of internet access is 13 years. This age is decided by Congress in, which prohibits the Website from collecting information about children younger than 13 years without parental consent. The American Academy of Pediatrics (AAP) encourages that age should be respected. Therefore, age faking has become common practice by some preadolescents and some parents, but this action is a risk to the safety of their children.

According to a report by the European Union (2014), about half of all 11-to 16-year-olds have experienced one or more of the 10 risks we are asking for. With the recent increase among girls and younger children in some countries, the change from 2010 to 2014 shows that children are experiencing more risks and opportunities - in Denmark, Italy, and Romania (and, less, in Ireland). In addition, in Belgium, Portugal and the UK, children are now benefiting from more online activities without an equivalent increased risk. Therefore, the risks faced by online teens are like those faced offline (Carroll \& Kirkpatrick, 2011)

\section{Cyberbullying and Online Harassment}

Cyberbullying is defined as an individual or group wisely using information and communications involving electronic technology to facilitate intentional and repeated harassment or threats to another individual or group by sending or posting cruel texts or graphics using technological means (Mason, 2008). Cyberbullying is any behavior conducted through electronic or digital media by individuals or groups that repeatedly communicate hostile or aggressive messages intended to pose a danger or discomfort to others outside the school grounds and follow the target to their home (Hinduja \& Patchin, 2008). The use of social media also creates opportunities for emotional distress by receiving threatening, harassing, or embarrassing communications from other teenagers. This is a common threat to adolescents and pre-adolescents. Cyberbullying looks similar in prevalence to offline bullying; and current data shows that online harassment is not as common as offline harassment (Tarantino et al., 2013). Furthermore, cyberbullying can occur in any young person online, and can lead to profoundpsychosocial outcomes such as depression, anxiety, severe isolation, and tragic, suicide. Monash University found in their study that most surveyed secondary school students (72.4 per cent) indicated they had received unwanted or unpleasant contact by strangers through their social network profiles (Monash University,2011). Cyberbullying has been shown to cause higher levels of depression as well for victims than traditional bullying. It has also been linked to a teenage suicide case with teenagers known to be involved in reading hurtful comments a few days before their suicide attempt (Kowalski, 2010)The teens most at risk for cyberbullying are those who are at risk of offline harm, such as teenagers who have experienced sexual or physical abuse or those living in poor home environments (Kowalski, 2010)

\section{Sexting}

Sexual harassment encompasses a wide range of behaviors and can range in severity from demeaning statements to unwanted sexual advances and sexual assaults (Muehlenhard \& Felts, 1998). Unwanted online sexual solicitation is defined as "the act of encouraging a person to talk about sex, to do something sexual, or to share personal sexual information even when that person does not want to"(Ybarra \& Mitchell, 2007). Sexting can be defined as "sending, receiving, or forwarding sexually explicit messages, photos, or images through a mobile phone, computer, or other digital device(Attorney, 2010) 
Based on studies conducted in different countries, it was observed that this phenomenon is present among adolescents. (Livingston \& Bober, 2004)showed a difference between the number of children admitting exposure to pornography, and the much smaller number of parents who were aware of their children's exposure to it. Children also report daily use for hours longer than their parents report, and admit more often than their parents know, that they are subjected to online abuse (Cho \& Cheon, 2005); (Liau et al., 2008); (Livingston \& Bober, 2004)A study conducted in Washington in 2008 concluded that $20 \%$ of teens had sent or posted nude or seminude photos or videos of themselves (Ventura et al., 2011). Adolescents are much more likely to accept sexual solicitation between adolescents of the same age than sexual predation; and most of these invitations come from sameage colleagues known offline (Collins, 2011). In a study of European Union countries, 15\% of 11-16-year-olds have received peer to peer "sexual messages or images... [meaning] talking about having sex or pictures of naked people or having sex," and 3\% said they had sent or posted the message (Collins, 2011)

\section{Facebook Depression}

Facebook depression is defined as depression that develops when preteens and adolescents spend a lot of time on social media sites, such as Facebook, and then begin to show classic symptoms of depression (Davila et al., 2009). with offline depression, preadolescents and adolescents suffering from Facebook depression are at risk of social isolation and sometimes turn to risky internet sites and blogs for "help" that can promote substance abuse, unsafe sexual practices, or aggressive or self-destructive behavior (O'Keeffe \& Clarke-Pearson, 2011). Adolescents who use Facebook more often, show a more narcissistic tendency, while young adults who have a strong Facebook presence show more signs of psychological disorders, including antisocial, mania, and aggressive tendencies (APA, 2011).

Daily use of media and technology has a negative effect on the health of all children, preteen, and adolescents by making them more susceptible to anxiety, depression, and other psychological disorders, as well as making them more susceptible to future health problems (APA, 2011). Teens who are the heaviest media users, report less content and are more likely to report that they get into a lot of trouble, are often sad or unhappy, and often get bored (Rideout et al., 2010)

\section{Privacy Issues and Digital Footprint}

Currently, the main risks faced by preadolescents and online adolescents are the risk of each other, the risk of improper use of technology, lack of privacy, sharing too much information, or posting false information about themselves or (Barnes, 2006)

This kind of behavior compromises their privacy. When internet users visit various Websites, they can leave evidence of which sites they have visited. This collective and continuous record of a person's Web activity is called a "digital footprint." One of the biggest threats to young people on social media sites is that of their digital footprint and future reputation -O'Keeffe et al., 2011) Preadolescents and teens who have no awareness of privacy concerns often post inappropriate messages, pictures, and videos without understanding that "what can be online"(Palfrey et al., 2010). As a result, future jobs and college admissions can be put in jeopardy by inexperienced clicks. (O’Keeffe et al., 2011). 


\section{METHOD}

The research used highlights the benefits and consequences of social media for children and young people. Related to this, the authors conducted research using descriptive analysis methods with library studies. Research drafts include: 1) Topic selection, 2) Data exploration, 3) Ensuring the focus of research sourced from data obtained, 4) Sources of information collected in the form of data or empirical information sourced from novels, daily, research reports and other literature that support the theme of this study, 5) Reading literature sources, 6) Making research notes, 7) Digesting research notes, 8) Compiling reports. The information collection methods used are editing, organizing, and discovering. Instead create a method of information analysis using deductive and interpretive analysis. Thus, the purpose of this study is to describe the position of freedom of learning reviewed from the point of view of learning technology in era 4.0 and Community 5.0. The study is organized in a series of steps (described below) that lead to the development of a database containing all the characteristics of the selected paper. Details can be parsed using different viewpoints based on the database. This gives us a complete picture of the situation. The characteristics of freedom of learning are reviewed from learning technologies in the 4.0 era and literary societies 5.0 from around the world. Figure 2 depicts the entire rebuilding process.

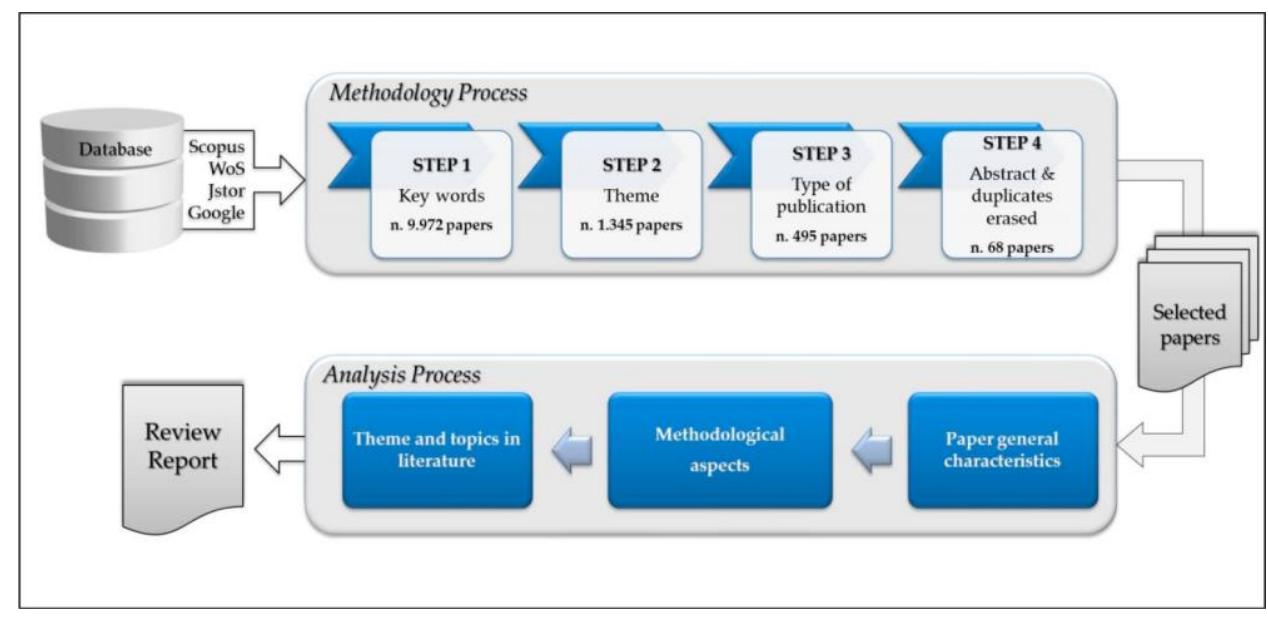

Figure 2. Review Process: Note Our Elaboration

\section{RESULT AND DISCUSSION}

\section{1. Research}

From the results of social media research that is often used by young people at this time is Instagram, WhatsApp, Tik Tok. Third Social Media is a social network where the most followers in the group of young people. These three applications are very popular applications among teenagers. a study of the top 10 social media that are often used by Indonesians include Facebook, WhatsApp, Facebook Messenger, Google+, Line, Twitter, Instagram, WeChat, and Pinterest. The ten social media share a reflection that the type of social media that is often used by Indonesians is social media as well as practical messaging applications.

4. 2 Positive and negative consequences of social media 
Social media networks also have positive consequences as well as negative consequences that greatly affect human life. Early on we want to start with the negative consequences of social media first.

a. Positive Consequences

\section{As a medium of dissemination of information}

Up to date data is very easy to spread through social networking web. In just a few minutes after the event, we can already enjoy the data. This is very useful for us as human beings living in today's digital age. The horizon of the world feels like it is at the touch of our fingers.

\section{As a facility to improve skills and social}

Honing technical and social skills is a necessity that must be crowded to survive and lies in the balance of competition in the modern era of today. This is very meaningful, there is no age limit, everyone needs to grow.

\section{Expand your friendship network}

By using social networks, we can talk to anyone, especially with people we do not know even from different corners of the world. This advantage can be used to raise knowledge, exchange minds, understand the culture and characteristics of each region, etc. This subject can also hone a person's language skills. For example, learn English by using the means of call or video call provided on the social network web. Since the web social networks of the kind mentioned above are very sucking public attention. Most spend hours visiting the web. Therefore, it takes a method to overcome this social network addiction such as by blocking the time of internet use, most notably the social network web. We also need to learn to use the internet network wisely so that we do not become people who want to be social networks. It should not be mandatory for users of the social network to end the total for not enjoying the web, but it is wiser if for a long time to reduce it is to reduce the hours of play Facebook, Twitter, and others.

\section{b. Negative Consequences}

1. Addiction to social networking web such as Facebook or Myspace can also harm health because it stimulates people to isolate themselves. Increased self-isolation can change gene working methods, confuse immunity responses, hormone levels, use of veins, and disrupt mental performance.

2. A person who spends his time in front of the pc should not often exercise so that addiction to this activity can give rise to a weak physical state, let alone obesity.

3. Physical destruction can also be very intertwined. If you use a mouse or press the phone keypad for hours every day, one can face repeated pressure cuts. Back pain is also a universally intertwined subject- in people who spend a lot of time sitting in front of a pc table.

4. Electronic media, such as pcs, laptops, or mobile phones (mobile phones) also destroy slowly- gradually the skills of children and young people to pursue social skills and read body language. It means that one would face a reduction in interaction with their neighbors in the number of minutes per day- it raises the number of people who cannot be talked to about a meaningful problem, so it continues to grow every day.

5. Cyber crime. Along with the development of technology, 
also grows evil. In the internet world, crime is known by the name of cybercrime. Cybercrime is very diverse. Among others, carding, hacking, cracking, phishing, as well as spamming.

6.Make time wasted in vain

For some time, I observed the attitude of social network users by connecting intensively with some users. One issue that often comes to my mind is how the user can continue online while it is in theory, they should again work, rest at night sleep, or again worship. Not often interactions I live with those who have a family, so it is not often I think how they control interaction with their family if each time spent by glaring at the screen of the pc and smartphone keyboard. I admit that some people do use social networks as a medium of business and look for referrals. But there are also those who use social networks to only chat with friends on Facebook or tweeters who when it is very cool to be less remember themselves and do not know the time.

\section{3. Methods to minimize the negative consequences of social media.}

To minimize the negative consequences of social media, need to be tried more intensive steps from the start of the family, learning institutions, the government as well as providers and organizers of the internet network itself.

From the family side, every parent should always have a good knowledge of the internet and they can direct their children to the negative impacts of the internet. In addition, they are also obliged to carry out controls about their children most importantly in terms of accessing any website site on the internet as well as with whom they associate in the virtual world. Parents must also actively direct the values of togetherness and family.

In terms of learning institutions should be able to direct the method of using healthy internet to their students. So that students when before using the internet and accessing social media has been equipped with sufficient knowledge to prevent negative influences that may arise. As well as holding activities that increase the side of togetherness such as scouting activities.

From the government side should be able to be a jury to create content and data spread on social media. The positives the government has tried to try are blocking access to pornographic sites that can disrupt the morale of the nation.

In terms of telecommunication service providers must also actively help the government to implement the blocking of access to content that can interfere with the morale of the most important citizens generic young.

\section{4. Method of using social media properly and correctly.}

1.Don't be so much of an individual's life. The availability of a column to share what you want to write does not mean that the whole must be in umbra in social media, especially a sensitive and very individual. For example, financial matters, romantic ties, about family life, or about aggravation with a person. Should not live on this subject save for consuming individuals do not publish for public news.

2.Do not dialogue and share content that has Sara factor and Pornography Avoid dialogue or write jokes that have factors SARA (Tribe, Religion and Race) and pornography. Because not only can offend other parties can also give rise to misconceptions and bring bad 
consequences. Not all social media users understand this concept, therefore start from we do not have dialogue and share content that has the above factors.

3.Stay away from updating the status related to the personal such as again at home or taking money at the Bank. This kind of renewal can be self-harming. If there is a man vowing evil, he can attend our home or attend where we are located.

4.Use the language that fits with who we are in contact with. It takes us to master who we are in touch with. Remember, not everyone is happy slang nor very polite language. One simple method to recognize a language that is matched with others is by using the style of the language used when sending a message writing status or responding to the status of others.

5. Respect the personal or secrets of others by not spreading them on social media, even with the purpose of joking or joking

\section{CONCLUSION}

Based on the studies cited in this paper, we concluded that social media is a very important platform in the daily lives of adolescents. They benefit by improving communication skills with friends and relatives and they can develop their socialization process more. Also, we can say that teenagers can use social media to get information on topics like health, education, and to improve technical skills using the latest technology. As a result, various forms of social media have changed the way teenagers talk, learn, and think. On the other hand, teens are in danger of Facebook depression, cyberbullying, and online sexual harassment. It should be asserted that the benefits and risks of adolescents in the utilization of social media have a significant influence on their physical and psychological development.

It is necessary to create parents and teacher's "awareness" of the risks faced by pre-adolescents and teenagers on social media. These two groups should encourage dialogue between youth and discuss in detail the risks that come from using this page and the impact it may have on them. However, studies in this direction are few and we are juggling broader studies in Indonesia and other areas of the problem.

\section{REFERENCES}

Akram, W., \& Kumar, R. (2017). A study on positive and negative effects of social media on society. International Journal of Computer Sciences and Engineering, 5(10), 347-354.

Attorney, B. D. (2010). Sexting. Pittsfield, MA: Commonwealth of Massachusetts. Retrieved from: Www. Mass.

Barnes, S. B. (2006). A privacy paradox: Social networking in the United States. First Monday.

Borja, R. R. (2005). Ethics Issues Snare School Leaders. Education Week, 24(18), 1-16.

Boyd, D. (2008). Why youth (heart) social network sites: The role of networked publics in teenage social life. YOUTH, IDENTITY, AND DIGITAL MEDIA, David Buckingham, Ed., The John D. and Catherine T. MacArthur Foundation Series on Digital Media and Learning, The MIT Press, Cambridge, MA, 2007-2016.

Carroll, J. A., \& Kirkpatrick, R. L. (2011). Impact of social media on adolescent behavioral health. Oakland, CA: California Adolescent Health Collaborative.

Ceyhan, A. A. (2011). University Students' Problematic Internet Use and Communication 
Skills According to the Internet Use Purposes. Educational Sciences: Theory and Practice, 11(1), 69-77.

Cho, C.-H., \& Cheon, H. J. (2005). Children's exposure to negative Internet content: Effects of family context. Journal of Broadcasting \& Electronic Media, 49(4), 488-509.

Collins, R. L. (2011). Content analysis of gender roles in media: Where are we now and where should we go? Sex Roles, 64(3-4), 290-298.

Federal Trade Commission. (2002). Protecting Children's Privacy Under COPPA : a Survey on Compliance. April.

Ghani, N. A., Hamid, S., Targio Hashem, I. A., \& Ahmed, E. (2019). Social media big data analytics: A survey. Computers in Human Behavior, 101, 417-428.

https://doi.org/10.1016/j.chb.2018.08.039

Hinduja, S., \& Patchin, J. W. (2008). Cyberbullying: An exploratory analysis of factors related to offending and victimization. Deviant Behavior, 29(2), 129-156.

Ito, M. (2013). Hanging out, messing around, and geeking out: Kids living and learning with new media. The MIT Press.

Ito, M., Horst, H. A., Bittanti, M., Herr Stephenson, B., Lange, P. G., Pascoe, C. J., \& Robinson, L. (2009). Living and learning with new media: Summary of findings from the digital youth project. The MIT Press.

Ito, M., Horst, H., Bittanti, M., Boyd, D., Herr-Stephenson, B., Lange, P., Pascoe, J., \& Robinson, L. (2008). Living and learning with new media: Summary of findings from the digital youth project. The John D. and Catherine T. MacArthur Foundation Reports on Digital Media and Learning. Cambridge: MIT Press.

James, H., \& James, H. (2009). The end of globalization: lessons from the Great Depression. Harvard University Press.

Kaplan, A. M., \& Haenlein, M. (2010). Users of the world, unite! The challenges and opportunities of Social Media. Business Horizons, 53(1), 59-68.

Kowalski, R. N. (2010). Alexis Pilkington Facebook horror: Cyber bullies harass even after suicide. Retrieved on June, 3, 2011.

Lara, S., \& Naval, C. (2012). Social networks, civic participation, and young people: A literature review and summary of the educational challenges. Active Citizen Participation in E-Government: A Global Perspective, 187-205.

Liau, A. K., Khoo, A., \& Ang, P. H. (2008). Parental awareness and monitoring of adolescent Internet use. Current Psychology, 27(4), 217-233.

Livingston, S., \& Bober, M. (2004). Taking up online opportunities. Children's Use of the.

Mason, M. (2008). Complexity theory and the philosophy of education. Educational Philosophy and Theory, 40(1), 4-18.

Muehlenhard, C. L., \& Felts, A. S. (1998). Sexual beliefs scale. Handbook of SexualityRelated Measures, 116-118.

O'Keeffe, G. S., \& Clarke-Pearson, K. (2011). The impact of social media on children, adolescents, and families. Pediatrics, 127(4), 800-804. 
O'reilly, T. (2007). What is Web 2.0: Design patterns and business models for the next generation of software. Communications \& Strategies, 1, 17.

Podobnik, V., Ackermann, D., Grubisic, T., \& Lovrek, I. (2013). Web 2.0 as a foundation for Social Media Marketing: global perspectives and the local case of Croatia. In Cases on Web 2.0 in Developing Countries: Studies on Implementation, Application, and Use (pp. 342-379). IGI Global.

Qi, J., Monod, E., Fang, B., \& Deng, S. (2018). Theories of social media: Philosophical foundations. Engineering, 4(1), 94-102.

Rideout, V. J., Foehr, U. G., \& Roberts, D. F. (2010). Generation M 2: Media in the Lives of 8-to 18-Year-Olds. Henry J. Kaiser Family Foundation.

Srivastava, P. (2012). Social networking \& its impact on education-system in contemporary era. International Journal of Information Technology Infrastructure, 1(2).

Surjandy, J. (2017). Do college students use e-book with smartphone?(Study for college student's subject in information technology). Proceedings of the International MultiConference of Engineers and Computer Scientists, 2.

Tarantino, K., Mcdonough, J., \& Hua, M. (2013). Effects of Student Engagement with Social Media on Student Learning: A Review of Literature. The Journal of Technology in Student Affairs, 1-13. http://studentaffairs.com/ejournal/Summer_2013/EffectsOfStudentEngagementWithSoci alMedia.html

Tikly, L., \& Barrett, A. M. (2011). Social justice, capabilities and the quality of education in low income countries. International Journal of Educational Development, 31(1), 3-14. https://doi.org/10.1016/j.ijedudev.2010.06.001

Ventura, S. J., Mathews, T. J., Hamilton, B. E., Sutton, P. D., \& Abma, J. C. (2011). Adolescent pregnancy and childbirth-United States, 1991-2008. CDC Health Disparities and Inequalities Report-United States, 2011, 60, 105.

Wright Joe, J. (2015). Assessment of Social Media in the Library: Guidelines for Administrators. Journal of Library Administration, 55(8), 667-680. https://doi.org/10.1080/01930826.2015.1085251

Zachos, G., Paraskevopoulou-Kollia, E. A., \& Anagnostopoulos, I. (2018). Social media use in higher education: A review. In Education Sciences (Vol. 8, Issue 4). MDPI AG. https://doi.org/10.3390/educsci8040194

Zafarani, R., Abbasi, M. A., \& Liu, H. (2014). Social media mining: an introduction. Cambridge University Press. 